\title{
Common Warts Treatment by Intralesional (60,000 Versus $120,000)$ IU of Vitamin D3, Comparative Study
}

\author{
Ruya Thamer Ihsan Mahmoud ${ }^{1}$, Mazin Hamid Ayyash ${ }^{2}$ \\ ${ }^{1}$ Scholar Researcher, M.B.Ch.B., Kirkuk University 2010-2011, \\ ${ }^{2}$ Assistant Professor, FICMS, Higher Diploma in Laser, College of Medicine, Tikrit University
}

\begin{abstract}
Background: Wart is common disease cause by infection with HPV, there are many modalities for treatment most of them resolve wart with many side effects as scars and recurrence.

Objective: To identify the significant difference between two doses of intralesional vitamin D3 (60,000 vs $120,000)$ iu injection in treatment of warts.

Patients and Method: A total of 47 patients were included in the study divided into two groups. Group A received intralesional 60,000 iu of vt.D3, and group B received intralesional 120,000 iu vt. D3 into each lesion with maximum of five warts treated in one session. Four sessions was done every 2 weeks in both groups. Follow-up was done for 4 months after last session of treatment for any recurrence.

Results: In group A: complete response in $77.7 \%$, partial response in $6.67 \%$, minimal response in $6.67 \%$, and no response in $6.67 \%$ of patients. About $60 \%$ of patients with multiple warts showed complete clearance of distant untreated warts. In group B: complete response in $66.7 \%$, partial response in $6.67 \%$, minimal response in $20 \%$, and no response in $6.67 \%$ of patients. There was no significant difference between both groups. No recurrence was observed in both groups in the follow-up period.
\end{abstract}

Conclusions: Immunotherapy by both intralesional MMR vaccine and vitamin D3 is simple, well-tolerated, and effective.

Keywords: $H P V$, treatment, vitamin D3, warts.

\section{Introduction}

Wart: are benign cutaneous tumor and less commonly occur mucous membrane and caused by Human papilloma viruses (HPVs).

Common warts are hyperkeratotic, exophytic, domeshaped papules or plaques that are commonly associated with HPV-1, -2, -4, -27, or -57. spontaneous resolution may occur within 2 years in $65 \%-78 \%$ of warts, for most patients. ${ }^{[1]}$

It replicates simultaneously with differentiation of keratinocytes, leading to the maturation of viral particles in the granular cell layer. The viral particles are released at same time with exfoliation of the verruca, causing spread to other regions. ${ }^{[3]}$

There is no viremic phase during the life cycle, therefore a systemic immune response is avoided. In addition, small amount of viral proteins is expressed in the basal and spinous cell layers of the epidermis, where they would be most likely to be recognized by Langerhans cells and infiltrating lymphocytes. ${ }^{2]}$

Clinical types of warts;Verruca vulgaris, Palmoplantar warts, Verruca plana, Filiform warts,Periungual wart,Mucosal wart.Diagnosis:warts are usually diagnosed clinically; Characteristic warty appearance with a rough, dry stippled surface, paring the surface of the wart will reveal capillary loops close to the surface and often causes bleeding. ${ }^{[4]}$

Treatment Involved: First line; Salicylic acid, Glutaraldehyde, Formalin, Occlusion,Topical 5-fluorouracil, Caustics, Retinoic acid, Vitamin D analogues 
Second line; Cryotherapy, Laser, Hyperthermia, Surgery, Photodynamic therapy

Third line; Podophyllin and podophyllotoxin, Imiquimod, Topical immunotherapy, Intralesional immunotherapy,Interferon, H2 receptor antagonists, Zinc, Oral retinoids, Intralesional bleomycin, Cidofovir, Psychological method.

Vitamin D; It is a group of fat-soluble secosteroids responsible for enhancing intestinal absorption of calcium, magnesium, and phosphate, and has multiple other biological effects. ${ }^{[1]}$ In humans, the important compounds in this group are vitamin D3 (also known as cholecalciferol) and vitamin D2 (ergocalciferol). ${ }^{\text {[7] }}$

The Mechanism of Action of Vitamin D3 Analogues

Cells in the skin have receptors for Vitamin D3 analogues are keratinocytes, Langerhans' cells, melanocytes, fibroblasts and endothelial cell ${ }^{[6]}$, so

1. It works through Vitamin D receptor (VDR) to regulate cell growth, differentiation and immune function. It inhibits the proliferation of keratinocytes and modulates epidermal differentiation

2. Vitamin D prevent production of several proinflammatory cytokines by $\mathrm{T}$-cell clones, including IL-2 and IFN- $\gamma$.

3. It inhibits interleukin-6 (from B cell) and interleukin-8 (that produced from macrophage).

4. It inhibits transcription of granulocyte-macrophage colony-stimulating factor and messenger ribonucleic acid.

5. It block activity of cytotoxic $\mathrm{T}$ cells and Natural Killer cells. ${ }^{[8]}$

\section{Patient and Method}

The study was conducted in the departments of dermatology of Salahuldin-General Hospital in Tikrit city and Azadi Teaching Hospital in Kirkuk city, Iraq. From Nov. 2019 to 30 June 2020. It was an opened, a comparative and a therapeutic trial study to estimate the efficacy of the vit. D3 in different two doses to treat wart. A total of 47 patients were enrolled in the study. 27 of them treated with 60,000 IU of vit. D3 as group (A) and other 20 patient treated with 120,000 IU of vit.
D3 as group (B). The study targeted male and female from 9 to 60 years old. Exclusion criteria involved Immunosuppressed patient. Pregnant women's. Lactating women's. Patient on other treatments modalities of wart in previous 2 weeks of injection. Prior history of hypersensitivity to vit. D3 .

\section{Clinical Response:}

- Clinical response determined by reduce in the number and size of warts.

- Complete response achieve when all of wart included (treated warts and distant warts) resolved completely $100 \%$.

- Moderate response achieve when $>50 \%$ to $<100 \%$ reduce in both size and number of lesion.

- Mild response achieve when $1 \%$ to $<50 \%$ of reduction occur. ${ }^{[5]}$

\section{Materials}

- 27 gauge insulin syringe.

- $\quad$ vit. D3 ampule 300,000 IU/ml.

Method of Administration of Vitamin D3 Injection:

We give slow gentl intralesional injection of vitamin D3 without local anaesthesia after proper encourgement and reasurance to the patients.

- Patients in group 1 A (no. $=27)$ were treated with $60,000 \mathrm{IU}$ vit. D3 $(0.2 \mathrm{ml}$ of $1 \mathrm{ml}$ of vit. D3 300,000 IU) whereas group $2 \mathrm{~B}($ no. $=20)$ were treated with $120,000 \mathrm{IU}$ vit. D3 $(0.4 \mathrm{ml}$ of $1 \mathrm{ml}$ of vit. D3 $300,000 \mathrm{iu})$, vit. D3 injected to the base of wart with 27 gauge insulin syringe (Figure 18).

- $\quad$ The injections were repeated 2 weeks apart; for 4 sessions.

- The large number of wart treated in single session were 5 warts.

- Follow up of recurrence will obtained after 4 months of last injection.

\section{Results}

Demographics and clinical informations of the patients in each groups were mentioned in table 1 with no statistically significant difference between both groups. 


\begin{tabular}{|c|c|c|c|}
\hline Data & Group A (no. $=27)$ & Group B (no. $=20)$ & P. value t. Test \\
\hline Dose of vt.D3 & $60,000 \mathrm{iu}$ & $120,000 \mathrm{iu}$ & \\
\hline $\begin{array}{l}\text { Sex } \\
\text { Male } \\
\text { Female } \\
\text { Ratio: F:M }\end{array}$ & $\begin{array}{c}9(33.3 \%) \\
18(66.6 \%) \\
\text { Ratio } 2: 1\end{array}$ & $\begin{array}{c}9(45 \%) \\
11(55 \%) \\
\text { Ratio: } 1.2: 1\end{array}$ & \\
\hline $\begin{array}{l}\text { Age (years) } \\
<25 \\
>25 \\
\text { Min-Max } \\
\text { Mean } \pm \text { SD } \\
\text { Median }\end{array}$ & $\begin{array}{c}19(70 \%) \\
8(29.6 \%) \\
3-48 \\
19.3 \pm 12.6 \\
18\end{array}$ & $\begin{array}{c}16(80 \%) \\
(20 \%) \\
8-50 \\
20 \pm 10.5 \\
19\end{array}$ & \\
\hline $\begin{array}{l}\text { Previous Treatment } \\
\text { No } \\
\text { Yes }\end{array}$ & $\begin{array}{l}15(55.5 \%) \\
12(44.4 \%) \\
\end{array}$ & $\begin{array}{l}11(55 \%) \\
9(45 \%) \\
\end{array}$ & \\
\hline $\begin{array}{l}\text { No. of wart } \\
\text { Single } \\
\text { Multiple }\end{array}$ & $\begin{array}{c}9(33 \%) \\
18(66.6 \%) \\
\end{array}$ & $\begin{array}{l}11(55 \%) \\
9(45 \%)\end{array}$ & \\
\hline $\begin{array}{l}\text { Maximum diameter of treated } \\
\text { wart }\end{array}$ & $40 \mathrm{~mm}$ & $35 \mathrm{~mm}$ & \\
\hline $\begin{array}{l}\text { Mean of diameter before } \\
\text { treatment }\end{array}$ & $10.7 \mathrm{~mm}$ & $16.9 \mathrm{~mm}$ & \\
\hline $\begin{array}{l}\text { Mean of diameter after } \\
\text { treatment }\end{array}$ & $1.18 \mathrm{~mm}$ & $4.9 \mathrm{~mm}$ & \\
\hline $\begin{array}{l}\text { Duration in months } \\
\text { Min-Max } \\
\text { Mean } \pm \text { SD } \\
\text { Median } \\
\end{array}$ & $\begin{array}{c}2-36 \\
11.2 \pm 10.5 \\
6 \\
\end{array}$ & $\begin{array}{c}3-24 \\
12.65 \pm 8.5 \\
12 \\
\end{array}$ & \\
\hline Rate of complete response & $21(77.7 \%)$ & $11(55 \%)$ & $\begin{array}{c}\text { P. Value }=0.20 \\
\text { t. Test }= \\
1.475743\end{array}$ \\
\hline $\begin{array}{l}\text { Type of wart } \\
\text { Verruca vulgaris } \\
\text { Periungual } \\
\text { Filiform } \\
\end{array}$ & $\begin{array}{c}21(77.7 \%) \\
6(22.2 \%) \\
0(0 \%)\end{array}$ & $\begin{array}{c}17(85 \%) \\
1(5 \%) \\
2(10 \%) \\
\end{array}$ & P. Value $=0.214$ \\
\hline $\begin{array}{l}\text { Side effect of vt.D3 injection } \\
\text { Yes } \\
\text { No }\end{array}$ & $\begin{array}{l}15(55.5 \%) \\
12(44.5 \%)\end{array}$ & $\begin{array}{l}17(85 \%) \\
3(15 \%)\end{array}$ & \\
\hline Relapse & $1(4.7 \%)$ & $0(0 \%)$ & \\
\hline
\end{tabular}

Regarding to the response of wart to treatment (table 1) show that group $\mathbf{A}$ has $77.7 \%$ complete response, $14.8 \%$ moderate response and $7.4 \%$ mild response (2 patients of 27 while in group B has $55 \%$ complete response, $35 \%$ moderate response and $10 \%$ mild response with no significant difference between groups ( $p$ value $=0.3130)$.

Relationship between clinical response and numbers of sessions shown in table 2, group A there's 6 patients (28.5\%) of patients have complete response after 2 sessions figure 1,9 patients $(42.8 \%)$ show complete response after 3 sessions and 6 patients $(28.5 \%)$ show complete response after 4 sessions while others show partial response after 4 sessions. In group B there's 5 patients $(45.5 \%)$ show complete response after 2 sessions figure 2, 4 patients (36.5\%) show complete response after 3 sessions and 2 patients (18.2\%) show complete response after 4 sessions while other patients have partial response after 4 sessions. No significant difference between groups ( $p$ value $=0.879$ ). 
Table 2: Relationship between complete response and number of sessions.

\begin{tabular}{|c|c|c|c|}
\hline No. of sessions & Group A No. $=\mathbf{2 1}$ & Group B No.=11 & p. value \\
\hline 2 & $6(28.5 \%)$ & $5(45.5 \%)$ & 0.879 \\
\hline 3 & $(42.8 \%)$ & $4(36.6 \%)$ & \\
\hline 4 & $6(28.5 \%)$ & $2(18.2)$ & \\
\hline
\end{tabular}

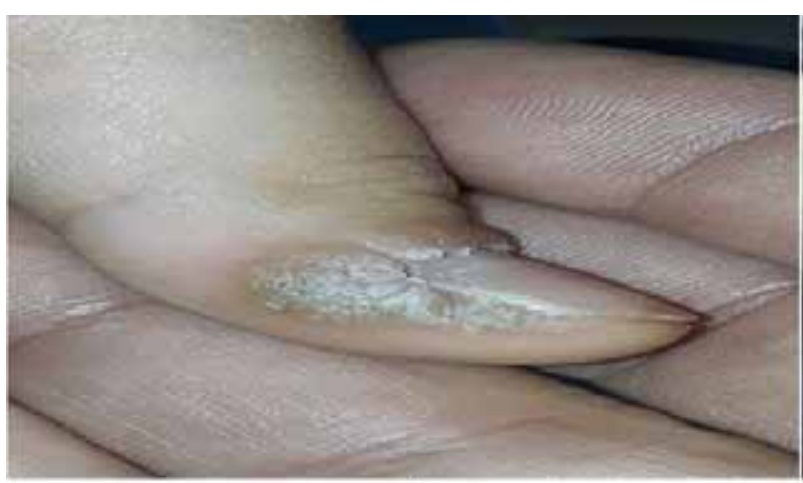

A.

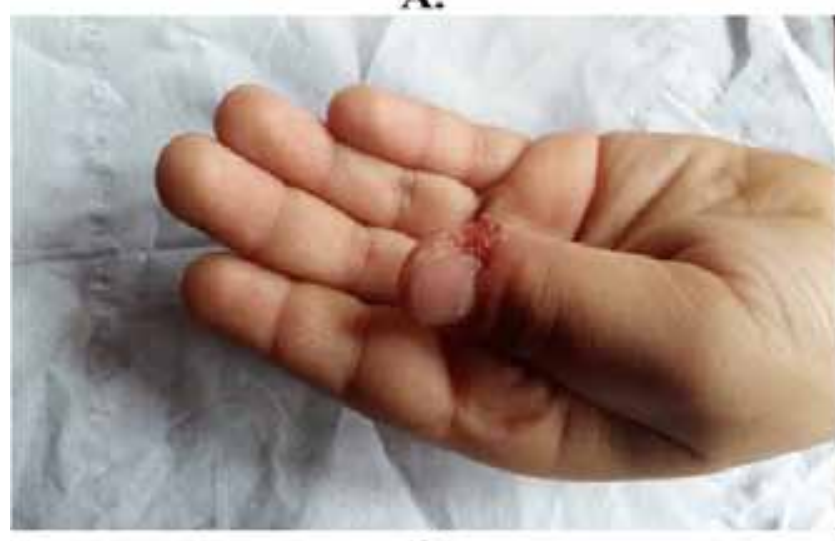

C.

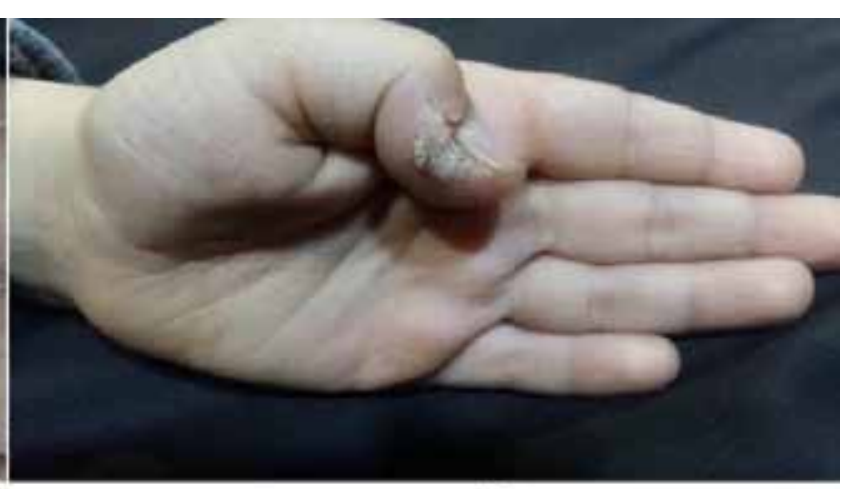

B.

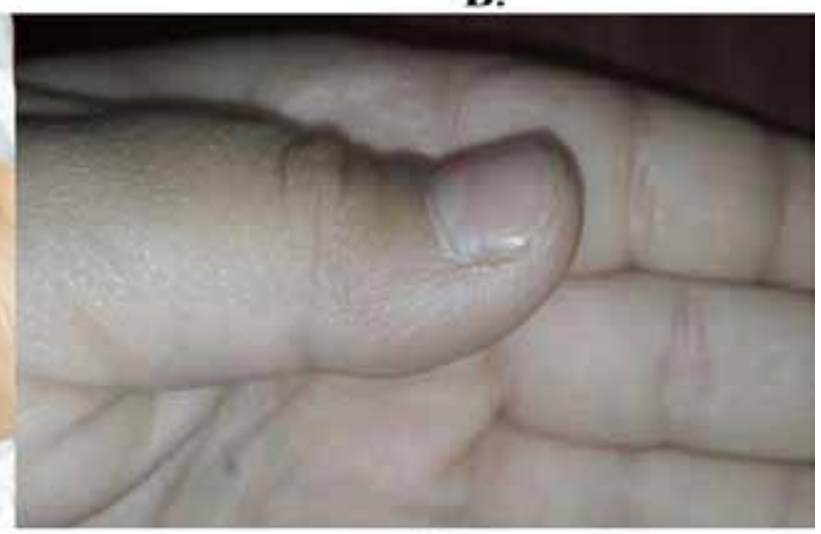

D.

Figure 1: Periungual wart for 11 years old boy since 1 year durations (A) before treatment, (B) after 2 weeks of treatment, (C) after 2 sessions, and (D) complete response after 3 sessions of treatments with vt.D3 60.000 IU.

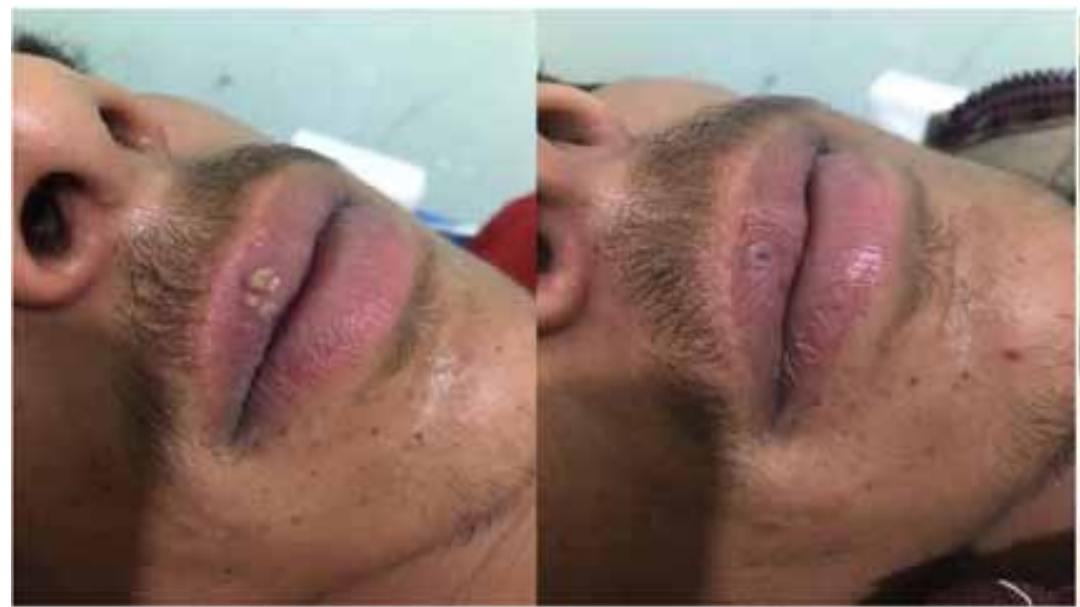

A.
B.

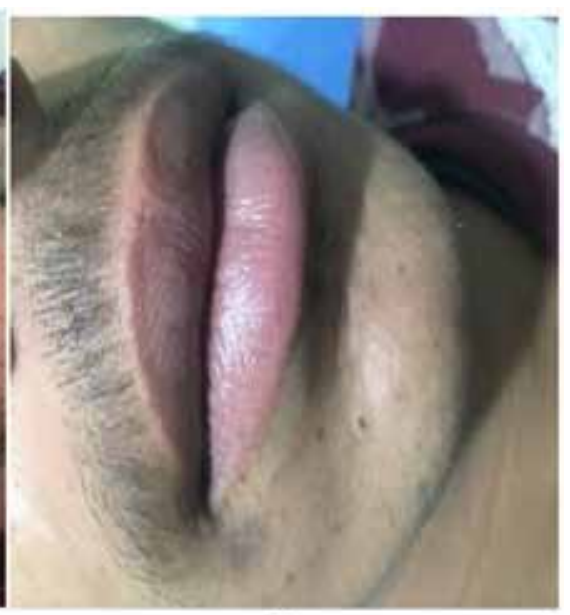

C.

Figure 2: Filiform wart on upper lips of 19 years old man for 5 months duration (A) before treatment, (B) after 2 weeks of $1^{\text {st }}$ session, and (C) after the second session of treatment with vt. D3 120,000 IU. 
Regarding reduction of the diameter of the wart (table 3), in group A the total diameter before treatment was $289 \mathrm{~mm}$ reduced to $32 \mathrm{~mm}$ there's significant difference $(p=0.004428)$, while in group $\mathbf{B}$ the total diameter of wart before treatment was $337 \mathrm{~mm}$ reduced to $97 \mathrm{~mm}$ after treatment also there's significant difference $(p=0.0000317)$. (Figure 33) show mean of diameters in both groups before and after injection.

Table 3: Comparison of clinical response regarding diameter of wart in both groups.

\begin{tabular}{|l|c|c|}
\hline Status of wart Diameters & Group A & Group B \\
\hline Before & $289 \mathrm{~mm}$ & $337 \mathrm{~mm}$ \\
Mean \pm SD & $11 \pm 9.3$ & $17 \pm 10.8$ \\
\hline After & $32 \mathrm{~mm}$ & $97 \mathrm{~mm}$ \\
Mean \pm SD & $1 \pm 2.7$ & $5 \pm 7$ \\
\hline P value & 0.004428 & 0.0000317 \\
\hline
\end{tabular}

Regarding to sides effect table 4 show in group $\mathbf{A}$ 15 patients $(55.5 \%)$ developed sides effect including erythema, pain, swelling and itching at site of injection with one patient developed pustule at site of injection.
In group B 17 patients (85\%) developed the same sides effect at site of injection with one patient developed vasovagal attack after injection immediately and resolved within minutes, other patient developed ulcer at site of injection. $(p=0.545)$.

Table 4: Side effects incidence in both groups.

\begin{tabular}{|l|c|c|c|}
\hline Side effects & Group A (No.=27) & Group B (No.=20) & P value \\
\hline Negative & $12(44.4 \%)$ & $3(15 \%)$ & 0.545 \\
\hline Positive & $15(55.5 \%)$ & $17(85 \%)$ & \\
\hline Erythema & $2(13.3 \%)$ & $2(11.7 \%)$ & \\
\hline Pain & $1(6.6 \%)$ & $1(5.8 \%)$ & \\
\hline Itching & $0(0 \%)$ & $2(11.7 \%)$ & \\
\hline Swelling & $2(13.3 \%)$ & $0(0 \%)$ & \\
\hline All of them & $10(66.6 \%)$ & $12(70.5 \%)$ & \\
\hline
\end{tabular}

Regarding clearance of distal warts in group A there's one patient with distal wart who has no improvement while in group B there's 5 patients $3(60 \%)$ of them getting improved of distal wart spontaneously with treatment of target wart.

There was no significant relation between clinical response and either age, sex, site of wart, type of wart and duration of disease in each groups.

\section{Discussion}

In our study there's 32 from 47 patients with complete clearance $68 \%$ and 11 patients with moderate response $23.5 \%$ and 4 patients with mild response $8.5 \%$.

\section{Our results match with many studies as:}

Shalmoud et al (2020) reported $66.7 \%$ of patient's complete response, $6.67 \%$ had partial response, $20 \%$ had minimal response, and $6.67 \%$ had no response. ${ }^{[9]}$

Raghukumar et al18(2017) reported complete response in $90 \%$, partial response in $6.66 \%$, and no response in $3.33 \%{ }^{[10]}$

Aktaş et al (2016) recorded complete clearance in $70 \%, 15 \%$ had a partial response, and $15 \%$ showed no response. ${ }^{[11]}$ 
Kavya et al (2017)19 study revealed complete clearance in $78.57 \%, 14.28 \%$ had a partial response, and $7.14 \%$ showed minimal response. ${ }^{[5]}$

Regarding to high complete response rate in study of Raghukumar et al may related to high dose $(600,000$ IU) uses.

Also our results match with Chia-Han Yeh M et al (2019) who has fourteen studies with 480 patients in which $59.9 \%$ patients $(95 \% \mathrm{CI}: 45.5 \%-72.9 \%)$ receiving intralesional vitamin D3 injection achieved complete resolution. ${ }^{[12]}$

Kareem et al (2019) who involved 30 patients as cases group who received intralesional injection of 0.2 $\mathrm{mL}$ of vitamin D3 (300,000 IU) into the base of mother wart for two sessions, 1 month apart, photographs were taken before injection then after 1 month and 3 months of injection. Complete clearance of the target injected warts occurred in $40 \%$ of patients, partial response occurred in $23.3 \%$ in patients in cases group; and there was no change in $36.7 \%$ of patients. ${ }^{[13]}$

Relatively there is low rate of complete response in this study which may be due to less numbers of injection with long duration between each session.

El Sayed et al (2020) there's 3 groups of patients group 1 treated with intralesional $2 \%$ zinc sulfate, group 2 intralesional 2\% vt. D3 and group 3 intralesional normal saline for 4 sessions each 2 weeks the complete response rate with vt. D3 in this study was $62.9 \%$ and this rate is relatively similar to our study. ${ }^{[14]}$

In our study there's no significant difference between group $\mathbf{A}$ and $\mathbf{B}$ in clinical response to different doses of vitamin D3 which was in group A 21 patients from 27 patients with complete response $77.7 \%$ and in group $\mathbf{B}$ 11 patients from 20 patients with complete clearance $55 \%(p$ value $=0.20)(t$ test $=1.475743)$, but there's a significant difference in the reduction of the diameter of the wart which was in group B $337 \mathrm{~mm}$ before treatment and be $93 \mathrm{~mm}$ with $\mathrm{p}$ value 0.0000317 compare to group A which was $289 \mathrm{~mm}$ before treatment and be $32 \mathrm{~mm}$ after treatment with $\mathrm{p}$ value 0.004428 .

This result refers to ability of 120,000 IU of vitamin D3 to be superior on 60,000 IU of vitamin D3 in treatment of wart but the results of nonsignificant difference in other measures between two groups may be due to the larger diameter of the warts in group $\mathbf{B}$ which may require for more sessions to achieve the better response.
Regarding to the complete response and numbers of sessions it was in group A 6 patients (28.5\%) after 2 sessions, 9 patients (42.8\%) show complete response after 3 sessions and 6 patients $(28.5 \%)$ show complete response after 4 sessions while others show partial response after 4 sessions with no significant difference ( $p$ value $=1$ ) mean $\pm \mathrm{SD}$ was $3 \pm 7.9$.In group B there's 5 patients $(45.5 \%)$ show complete response after 2 sessions, 4 patients $(36.5 \%)$ show complete response after 3 sessions and 2 patients $(18.2 \%)$ show complete response after 4 sessions mean \pm SD was $2.7 \pm 2$, while other patients have partial response after 4 sessions with no significant difference $(p$ value $=0.121)$. No significant difference between groups ( $p$ value $=0.879$ ) .

Regarding clearance of distal warts in group A there's one patient with distal wart who has no improvement while in group B there's 5 patients $3(60 \%)$ of them getting improved of distal wart spontaneously with treatment of target wart.

Regarding to sides effect in group A 15 patients (55.5\%) developed sides effect including erythema, pain, swelling and itching at site of injection with one patient developed pustule at site of injection.

In group B 17 patients (85\%) developed the same sides effect at site of injection with one patient developed vasovagal attack after injection immediately and resolved within minutes, other patient developed ulcer at site of injection and there is no significant difference between two groups $(p=0.545)$.

Regarding to the recurrence of wart after 4 months of last injection for each wart in completely cured patients was one patient in group A (4.7\%) while no recurrence in group $\mathbf{B}$.

There were no significant relation between clinical response and either age, sex, site of wart, type of wart or duration of disease in each groups as in Shalmoud et al. $^{[9]}$

\section{Conflict of Interest: None}

Funding: Self

Ethical Clearance: Not required

\section{Reference}

1. Salman S, Ahmed M, Ibrahim A. Intralesional immunotherapy for the treatment of warts: A 
network meta-analysis. J AM ACAD DERMATOL. 2018;80(4).

2. Howley PM, Lowy DR. Papillomaviruses. In: Knipe DM, Howley PM, editors. Fields virology. 5th ed. Philadelphia: Lippincott Williams \& Wilkins; 2001. p. 2299-354.

3. Khanna N. Illustrated Synopsis of Dermatology and Sexually Transmitted Diseases. 5th ed. Delhi/ India: Elsevier; 2016.

4. KANG S, AMAGAI M, MARGOLIS D. Fitzpatrick's Dermatology. 9th ed. New York: McGraw-Hill Education; 2019.

5. Kavya M, Shashikumar B. Safety and efficacy of intralesional vitamin D3 in cutaneous warts: An open uncontrolled trial. Cutaneous and Aesthetic surgery. 2017;10(2):90-94.

6. Al Ghamdi, K. M., \& Khurram, H. (2011). Successful treatment of peri- ungual warts with diluted bleomycin using translesional multipuncture technique: A pilot prospective study. Dermatologic Surgery, 37(4), 486-492.

7. Shahriari M, Kerr PE, Slade K, et al. Vitamin D and the skin. Clin Dermatol. 2010;28(6):663-668.

8. Gautam D, Agarwal D, Nikalji D. DYP SURVIVAL GUIDE FOR POST GRADUATE DERMATOLOGY EXAMINATION PART-II. 2nd ed. India: Torrent Pharmaceuticals; 2013.
9. Shaldoum DR, Hassan GFR, El Maadawy EH, El-Maghraby GM. Comparative clinical study of the efficacy of intralesional MMR vaccine vs intralesional vitamin $\mathrm{D}$ injection in treatment of warts. J Cosmet Dermatol. 2020;00:1-8.

10. Raghukumar S, Ravikumar BC, Vinay KN, et al. Intralesional Vitamin D3 Injection in the Treatment of Recalcitrant Warts: A Novel Proposition. J Cut Med Surg. 2017;21(4):320-324.

11. Aktaş H, Ergin C, Demir B, et al. Intralesional vitamin $\mathrm{D}$ injection may be an effective treatment option for warts. J Cutan Med Surg. 2016;20(2):118122.

12. Chia-Han Yeh M, Tsai T-Y, Huang Y-C, Intralesional vitamin D3 injection in the treatment of warts: A systematic review and meta-analysis, Journal of the American Academy of Dermatology (2019)

13. Kareem IMA, Ibrahim IM, Mohammed SFF, Ahmed AA-B. Effectiveness of intralesional vitamin D3 injection in the treatment of common warts: Single-blinded placebo-controlled study. Dermatologic Therapy. 2019;32:e12882.

14. El Sayed MH, Sayed FS, Afify AA. Intralesional zinc sulfate $2 \%$ vs intralesional vitamin $D$ in plantar warts: A clinicodermoscopic study. Dermatol Ther. 2020;33(3):e13308. doi:10.1111/dth.13308 